\title{
WATER QUALITY OF INDIAN CREEK-VAN BUREN WATERSHED, IOWA AND MISSOURI
}

\section{U.S. GEOLOGICAL SURVEY}

Open-File Report 80-677

Prepared in cooperation with

\section{U.S. SOIL CONSERVATION SERVICE}

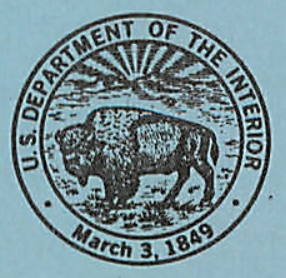




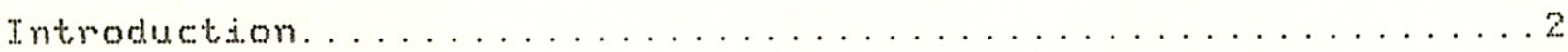

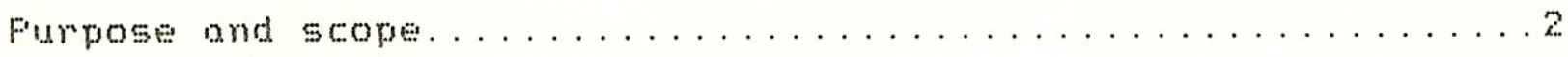

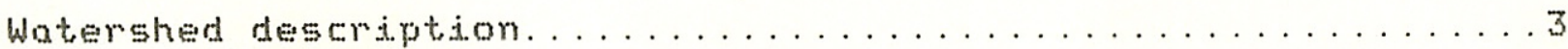

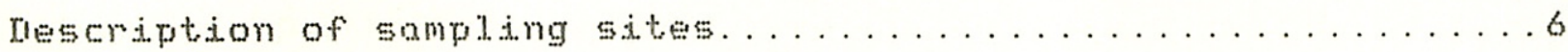

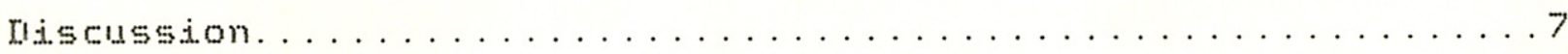

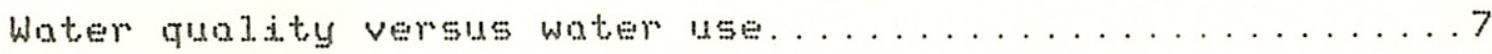

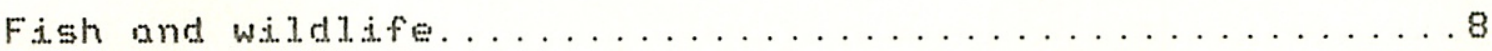

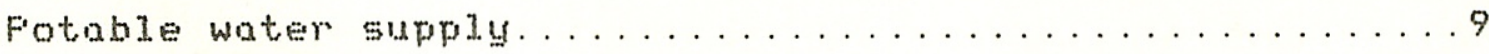

Feach water guatity. . . . . . . . . . . . . . . . .

seasonal water gualdet. . . . . . . . . . . . . . .

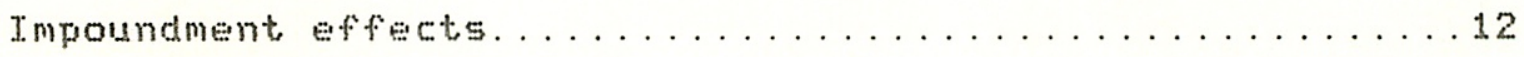

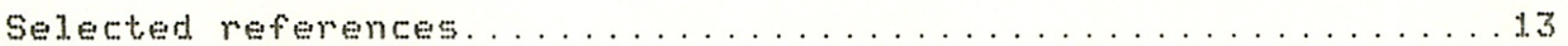

\section{I.....USTFATTONS}

Figure 1. Location of Indian Creet-Van Buren Watershed......3

Figure 2. Location of waten-quality stations in Indian

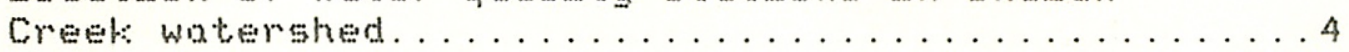

TAELES

Table 1. Water Quality Standards and criteria..........4

Table 2. Water Quality tota for Indian Crest............ 
WATER RUALITY OF INIIIAN CFEEK-VAN EUREN WATERSHEI

EY

Larmy J. Slack:

Marl: G. Iletroy

\section{AESTFIACT}

Generaliy, the water quality of Indian Creek-Van Euren watershed is suitable as a source of municipal, industrial and agricultural water supply and for fish and wildidfe. This suitahility is based upon comparisons of the existing water quality of Indian Creet: to Federal and State water quality standards and criteria developed for the protection of water sources and the fish and wildife that inhabit these waters. The water in the hasin is a calcium-magnesium-hicarhonate type that is low in dissolved solids. Concentrations of nutrients and metals, except iron, are low. Two pesticides, diazinon and dieldrin were detected in trace amounts within the stream. Variations in water quality were evident from station to station and from season to season. Water quality was more homogeneous during the period of high flow and generaliy poorest during the period of least flow. 
INTFOIUCTION

The Soil Conservation Service, U.S. Ilepartment of Agriculture, intends to implement a flood-prevention and land treatment project in the Indian Creek-Van Euren watershed, under the authority of the Watershed Frotection and Flood Frevention Act (Fublic Law 566, U.S. 83d Congress, 1954, 2d 5ession, 68 Stat. 666), as amended.

The flood prevention project includes nine flood water retarding structures and a nultiple purpose structure which will provide a new source of municipal, industrial, and agricultural water supply and provide habitat for fish and wildlife development.

The Soil Conservation Service requested the U. S. Geological Survey, Water Resources Ilivision to assess the existing water quality of the watershed for its adequacy toward meeting the project gonls.

\section{FURFOSE ANI SCOFE}

The primary purpose of this investigation is to assess the pre-impoundment water quality of the Indian Creek-Uan Euren watershed hy (1) relating the existing water quality of the watershed to the proposed water resource uses (2) compraring the water quality of the stream reaches described by the three sampling sites investigated and (3) describing water quality changes in the watershed from season to season. A secondary 
objective is to discuss the probable effects of impoundment on water quality of the watershed.

The investigation spanned 16 months, May 1978 to September 1979. The scope included the collection, analysis, and interpretation of four sets of water samples at three sites within the watershed.

\section{WATERSHEI IIESCRIFTION}

The location of the watershed is shown in figure 1 and the locations of the sampling sites in figure 2. The Indian Crewt:Van Euren watershed is in Van Buren County, Iowa, with a small

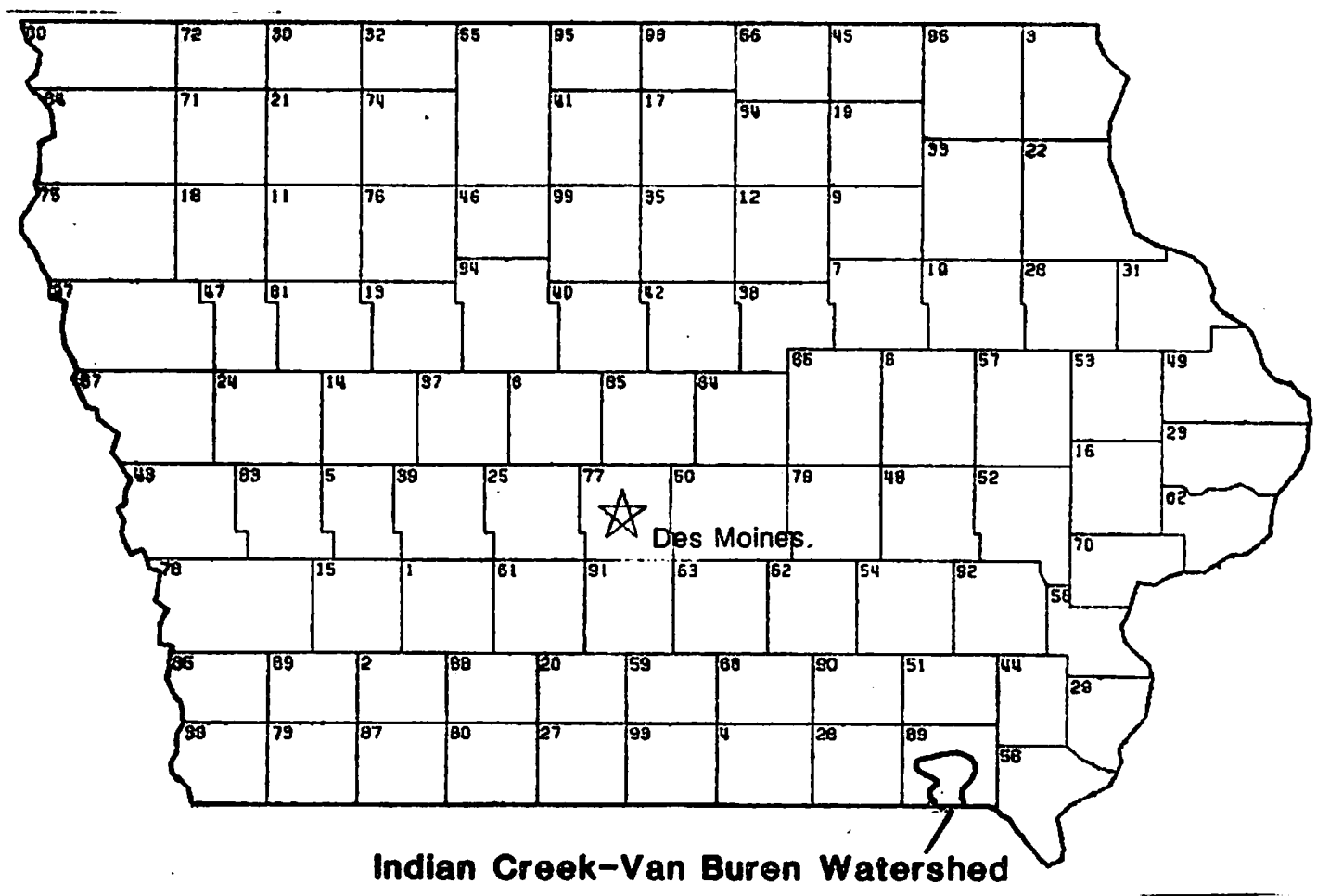

Figure 1.-Location of Indian Creek-Van Buren Watershed 


\section{VAN BUREN COLNTY IOWA}

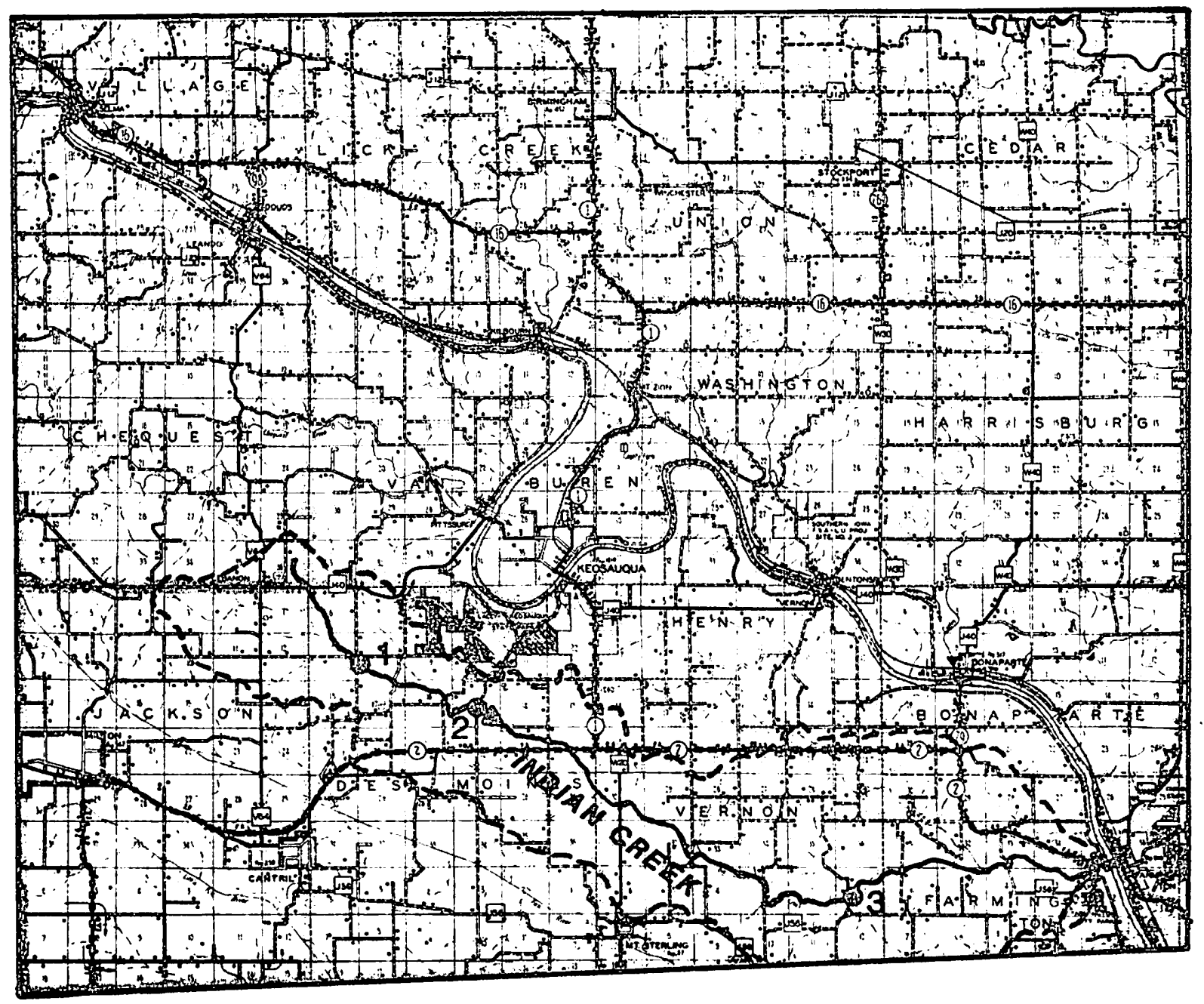

EXPLANATION

1 Indian Creek Water Quality Station, Location, and Number

-- Basin Boundary

ه Principle Structure $M-4$

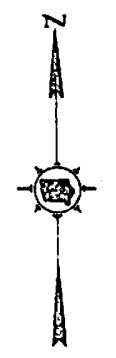

Figure 2.-Location of water-quality stations in Indian Creek watershed 
part extending into northeastern Missouri. The watershed has a total drainage area of 72.75 square miles; is approximately 27 miles long; and at its widest segment ahout 6.2 miles acmoss. When completed, the normal surface pool will he 574 acres. Indian Creek flows in a southerasterly direction and flows into the Iles Moines fiver near Farmington. Iowa. No cities or towns are located within the watershed, however, Keosauqua, the county seat of Van Euren County, is located 3 miles north of the watershed.

Land use in the watershed is 56 percent cropland, $28 \%$ pastureland, $12 \%$ forestland, and $6 \%$ other. Agricultural cropland is more predominate downstream of the planned multiple purpose structure, the areas associated with the future pool and upstream from the pool are hetter characterized hy pasture and woodland pasture. The principal soil association type is LindleyWeller-Gosport.

Most of Indian Creet: is perennial, however the stream becomes intermittent ahout 3 miles below County Highway V64. The lower reaches of Flat Rock Creek, White Dak Creek and South Fork Indian creet: are also classified as intermittent. The upper reaches of these streams and other tributaries in the project area are ephemeral. Computed average discharge at the mouth of Indian creek is 54 cubic feet per second ( $\left.\mathrm{ft}^{3} / \mathrm{s}\right)$.

The normal annual precipitation for southeast Iowa is 33.6 inches hut within the project area ranges from ahout 32 to more 
than 35 inches. Twenty three inches of precipitation normally falls during the G-month period from April through September. Average annual air temperature in southeastern Iowa is $51.6^{\circ} \mathrm{F}$ $\left(10.9^{\circ} \mathrm{C}\right)(\mathrm{Cob} 1 \mathrm{e}$ and Foherts, 1971).

\section{IIESCRIFTION OF SAMFLING SITES}

The number and location of sampling stations were jointiy determined by the U.S. Geological Survey and the Soil Conservation Service on the hasis of the following:

1. Location of dams--it was deemed nessessary to have at least one station above and one station below existing or proposed floodwater-retarding structures.

2. Location of roads--all the stations had to be accessible during adverse sampling conditions.

3. Hydrologic factors--the streans had to be flowing during planned times of water-quality sampling.

Station 1 (see Figure 2) (Arainage area - 7.8 square miles) is near the upstream limits of the future pool, 4.7 miles upstream from the proposed dam. Station 2 (drainage area $=16.5$ square miles) is within the future pool, 0.8 miles upstream from the structure. 
Station 3 (drainage area - 48.2 square miles) is 12.8 miles downstrean from the structure. Average anmul discharges for the stations were calculated from the equation

$$
Q=0.77 \mathrm{~A}^{0.94}
$$

where: $Q=A v e r a g e$ annual discharge, in cubic feet per second, and $A=$ Irainage area, in square miles

This equation is hased on the average discharge-to-drainage areo relationship for selected south-central Iowa streams cagle and Heinitz, 1978).

Water quality samples were collected at the sampling stations four times during the investigation. Analytical results are presented in table 2. The July 2-3, August 7, and september 10 samples are representative of seasonal low flow. The May 10 sampling is representative of a spring high-flow period.

\section{UISCUSSION}

Water Ruality Versus Water Use

To relate the existing water quality of the watershed to the intended water use, the following standards and criteria were used: (1) Iowa Administrative Code (1977) - Ifepartment of Environmental Ruality, Standards for Class E Waters (for wildlife, aquatic Iife and secondary body contact) and class C Waters (for raw water source of potalile supply); (2) National Interim Frimary and Secondary dirinking Water Fiegulations f for finished water for public water system) (U.S. Environmental 
Frotection Agency, 1975, 1977a) and (3) Water Quality Criteria recommended hy EFA ccriteria for health, welfare and fish and wildlife) (1977b). Concentrations of many, but not all of the constituents identified in the above regulations and criteria were a part of this investigation. These are summarized in table 1. Only the standards set by the Iowa Administmative Code and the National Interin Frimary lirinting Water Fegulations have direct regulatory use. Water quality criteria and the secondary Water Fegulations were established as guidelines for waterquality assessment and water quality protection and are not directly enforcenble.

Water quality data obtained from sampling Indian Creet: are reported in table 2. All parameters except the field measurements, specific conductance, pH, dissolved oxygen and fecal coliform and fecal streptococci hacteria were determined at the U.S. Geological Survey Water Ruality Laboratory in Ilenver, Colo.

Fish and Wildiife

Comparison of the existing water quality to the standards for Class $B$ waters shows acceptable water for most parameters investigated. Levels of total iron exceeded the quality criterion level in 9 of 12 samples analyzed. The high values of iron are not likely to present a poblem to fish and wildidfe maintenance in the proposed reservoir; iron concentrations identified in this assessment are typical of Iowa waters and are 
from natural sources, primarily from iron adsorbed on or precipitated on suspended sediment. of 12 samples analyzed, 3 samples exceeded standards for mercury and 1 sample exceeded standards for copper for class waters. Lead and chromium levels in Indian Creek: were below btandards.

The Environmental Frotection Agency has recommended that the concentrations of phosphate not exceed $0.05 \mathrm{mg} / \mathrm{L}$ for water flowing into a reservoir to minimize the probahility of seasonal algal hlooms (U.S. Environmental Frotection Agency, 1977a). This criterion was minimally exceeded in five cases. Nitrate concentrations were all helow standards for B waters, pH values were all within limits for waters and all determinations of dissolved oxygen concentration were greater than $5 \mathrm{mg} / \mathrm{L}$ although minimum concentrations (5-6 mg/L) did occur at periods of minimal flow.

Concentration of phenols in the watershed were well below standards for Class B waters. FCN and FCE were not detected. Iliazinon was the only pesticide detected at all sampling sites. The maximum concentration of this pesticide detected was 0.04 ug/L in a sample collected at station 2 . Foum of the 12 samples contained detectable amounts of dieldrin. All other pesticides investigated were not detectahle in samples from the watershed. Levels of fecal coliform hacteria exceeded the Class E standard for 3 of the 12 samples; all cases occurring during minimal flow. 
Fotable Water Supply

Comparison of existing water quality to standards for class C waters did not identify any constituent of those measured which were in excess of acceptable standards. Class C standards are applicable to raw water sources. Comparison of determined water quality to standards for finished water (Frimary and Secondary Irrinfing Water Fegulations) can be used as a relative indicator of the extent of treatment that would be necessary for utilizing water from Indian Creete as a public water source.

Generaliy the water in Indian Creets is moderately hard (average hardness - $170 \mathrm{mg} / \mathrm{L}$ ) and contains an average dissolved solids concentration of $226 \mathrm{mg} / \mathrm{L}$. Levels of total iron ranging from $900 \mathrm{ug} / \mathrm{L}$ to $6400 \mathrm{ug} / \mathrm{L}$ indicate that removal of this constituent may be needed. Levels of bacteria are relatively high, ranging from less than 20 to 4700 colonies/100 $\mathrm{ml}$ (fecal coliform) and 110 to 250 colonies/100 ml (fecal streptococci). However, Indian Creets is located in an agricultural region where agricultural practices contribute significantly to increased levels of fecal hacteria.

of the parameters contained in the Interim frimary and Secondary Irinking Water Fegulations, only iron and fecal hacteria exceed standards. The remainder of constituents analyzed were below or within maximum contaminant, levels (MCL). MCL's specify the maximum permissible level of a contaminant in water which is delivered to the free flowing outlet of the 
ultimate user of a public water system (U.S. Environmental Frotection Agency, 1975).

Reach Water Ruality

Comparison of constituent values between the three sampling stations show moderate differences. Honogeneity of the stream was greatest during the high flow period of Mas 10; however, iron concentrations increased downstream. This homogeneity was not apparent during the low flow periods when constituent concentrations varied considerably with a few spatial trends evident. Sampling on July $2-3$ exhitited increasing concentrations downstream for iron and lead; the opposite being true for copper. Major ions, chromium and mercury concentrations on these dates showed little variation. Iluring the september 10 and August 7 sampling, chromium, copper, iron, lead and mercury and all nutrients except nitrate decreased in concentration upstream.

Seasonal Water Ruality

The data show that maxinum dissalved oxygen concentrations and minimum hacterial populations occured during the higher spring flow of May 10. Nutrient concentrations during this period were not high when compared to the other sampling dates. Sampling on July 2 and 3 , when flow was minimal, identified maximum concentrations at all stations for the constituents; copper, iron, lead, mercury, nitrate and other nitrogen constituents. lletectable amounts of diazinon were also present at all sites during this period. 
Impoundment Effects

Some of the probable beneficial effects of impounding water reported by Love (1961), Churchill (1957), and Hartung (1958) include: (1) an averaging or "evening out" of sharp variations in dissolved mineral concentrations, hardness, and $p H ;$ (2) a reduction in concentrations of turhidity, and perhaps color; (3) a reduction in average temperature; (4) a meduction in coliform bacteria densities; and (5) a sink-effect wherehy the suspended sediments (and attached chemicals) would drop out of the water due to a reduction in velocity of the in-flowing turhid water. Some of the probable detrimental effects reported by fish (1959), Love (1961), Churchill (1947), and Hull (1961) include: (1) reduced dissolved-oxygen concentrations, especially in the summer and in the deeper parts of the reservoir; (2) much wider variations in dissolved-oxygen concentrations; (3) increased growth of algae and associated undesirable tastes and odors; (4) increased concentrations of carbon dioxide and frequently irom. manganese, and other trace metals, and alkalinity, especially near the bottom; and (5) reductions in temperature. 
This page intentionally left blank 
TARLE 1. WATER RUALITY STANIARIIS ANR CRITERIA

\begin{tabular}{|c|c|c|c|c|c|c|}
\hline \multirow{2}{*}{ CONSTITUENT } & \multicolumn{2}{|c|}{$\begin{array}{l}\text { NATIONAL IIRINKING } \\
\text { WATER REGULATIONS }\end{array}$} & \multicolumn{2}{|c|}{$\begin{array}{l}\text { IOWA AIMINISTFATIVE } \\
\text { COIIE }\end{array}$} & $\begin{array}{r}\text { EFA } \\
\text { RUALITY }\end{array}$ & $\begin{array}{l}\text { WATER } \\
\text { CRITERIA }\end{array}$ \\
\hline & FFIMARY & SECONLIAF & E WATERS & $\begin{array}{l}\text { CLASTS } \\
\text { C WATERS }\end{array}$ & $\begin{array}{l}\text { WATEF } \\
\text { SUFFLY }\end{array}$ & $\begin{array}{l}\text { AOUATIIC } \\
\text { LIFE }\end{array}$ \\
\hline $\mathrm{pH}$ (units) & & $6.5-8.5$ & $: 6.5-9.0$ & $6.5-9.0$ & $5-9$ & $6.5-9.0$ \\
\hline 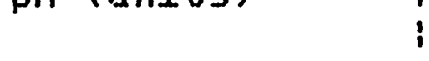 & & 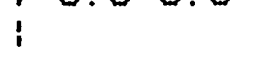 & ; & 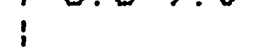 & $i$ & 0.07 .0 \\
\hline IISSOLVEII O2 & & ; & $\mathbf{i}$ & 25 & & $:$ \\
\hline$(m g / L)$ & & i & i & i & i & $i$ \\
\hline 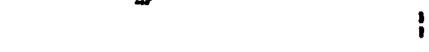 & & ! & i & i & i & $i$ \\
\hline SULFATE, $(m g / L)$ & & 250 & i & ! & 250 & $i$ \\
\hline 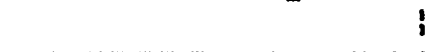 & & ! & i & i & i & i \\
\hline CHLOFIIE, $(\mathrm{mg} / \mathrm{L})$; & & 250 & 1 & 250 & 250 & $\mathbf{i}$ \\
\hline (a) & & $i$ & $i$ & 1 & $\mathbf{i}$ & i \\
\hline FLUORIIE, $(\mathrm{mg} / \mathrm{L}):$ & 2.4 & $i$ & i & 2 & $i$ & $\mathbf{i}$ \\
\hline i & & i & i & i & ; & $i$ \\
\hline IISSOLVEII SOLIIIS: & & 500 & i & ! & 500 & $i$ \\
\hline$(\mathrm{mg} / \mathrm{L})$ & & $i$ & i & $i$ & $i$ & $i$ \\
\hline 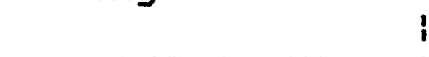 & & $i$ & i & i & i & $i$ \\
\hline NITRATE (asN) & 10 & i & i & 10 & 10 & $i$ \\
\hline$(m g / L)$ & & $i$ & i & $i$ & $i$ & i \\
\hline$i$ & & $i$ & i & i & $\mathbf{i}$ & $i$ \\
\hline CHFOMIUM, ( $(\mu \mathrm{g} / \mathrm{L}):$ & 50 & $i$ & 50 & 50 & 50 & 100 \\
\hline 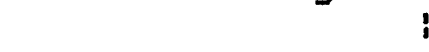 & & 1 & $i$ & 1 & 1 & 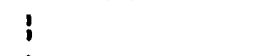 \\
\hline COFFER， (ug/L) & & 1000 & 20 & 1000 & 1000 & i \\
\hline 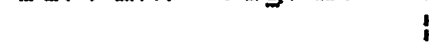 & & i & ! & i & $i$ & ! \\
\hline IRON, (ug/L) & 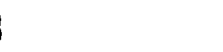 & 300 & $\mathbf{i}$ & i & 300 & 1000 \\
\hline 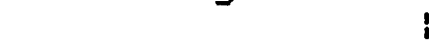 & & i & $i$ & 1 & $i$ & i \\
\hline LEAII, (ug/L) & 50 & $i$ & 100 & 50 & 50 & $i$ \\
\hline & & $i$ & $i$ & $\mathbf{i}$ & $i$ & $i$ \\
\hline MERCUFY, $(u g / L)$ & 2 & 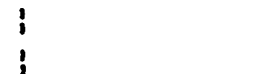 & .05 & 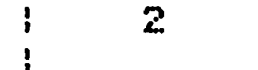 & 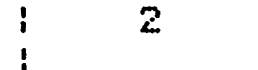 & .05 \\
\hline FHENOLS, (ug/L) & 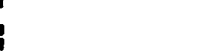 & $i$ & 50 & 50 & $i$ & 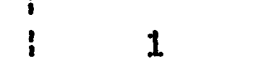 \\
\hline का & 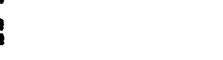 & $i$ & i & $i$ & $i$ & $i$ \\
\hline $\mathrm{FCB},(\mu \mathrm{g} / \mathrm{L})$ & 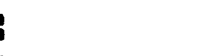 & 1 & $i$ & $i$ & $i$ & .001 \\
\hline & 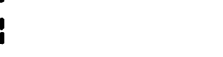 & $i$ & $i$ & $i$ & $i$ & $i$ \\
\hline IIELIRIN, $(\mu \mathrm{g} / \mathrm{L})$ & & i & $\mathbf{i}$ & $i$ & $i$ & .003 \\
\hline & & $\mathbf{i}$ & i & 1 & $i$ & $i$ \\
\hline FECAL COL & & $i$ & $i<2000$ & $i$ & i & $i$ \\
\hline$($ colonies $/ 100 \mathrm{ml})$ & & i & $i$ & $i$ & $!$ & $i$ \\
\hline
\end{tabular}


Table 2.-Water quality data Indian Creek-Van Buren Watershed

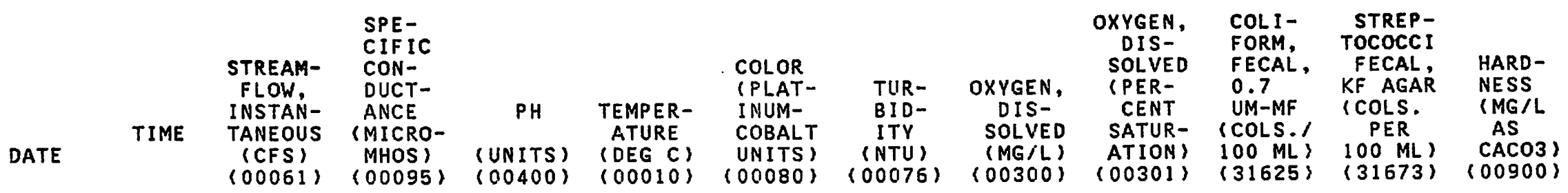

05490536 - BIG INDIAN C NO. 1 NR LEBANON, IA (LAT 404204 LONG 0920239 )

MAY , 1978

$10 \ldots 16781600$

$2.6 \quad 340$

$\begin{array}{rrrr}7.7 & 14.0 & 20 & 20 \\ 7.7 & 24.0 & 70 & 29 \\ 7.4 & 30.0 & 100 & 410 \\ 7.6 & 20.0 & 60 & 45\end{array}$

10.0

99190

92

160

$02 . .11600$

$<.01 \quad 330$

5.8

K150

200

140

AUG ... 0800

$.05 \quad 415$

6.0

79

$<20$

9300

160

$10 \ldots \quad 1300$

$1.0 \quad 330$

$-$

2500

360

150

05490540 - BIG INDIAN G. NO. 2 NR KEOSAUQUA, IA (LAT 404114 LONG 0915946 )

MAY , 1978

MAY 10781340

JUL $1979^{1340}$

AUǴ,... 1200

SEP $10 . . . \quad 1100$

$\begin{array}{llllrc}11 & 340 & 7.8 & 14.0 & 15 & 31 \\ <.01 & 320 & 7.6 & 25.0 & 120 & 160 \\ .10 & 355 & 8.0 & 28.0 & 30 & 4.7 \\ .00 & 300 & 7.5 & 18.0 & 15 & 10\end{array}$

9.4
5.4
5.8
--

93

300

110

160

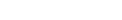

7.5

18.0

$-$

\begin{tabular}{l}
66 \\
74 \\
\hline
\end{tabular}

4700

05490550 - BIG INDIAN C NO. 3 NR MT. STERLING, IA (LAT 403741 LONG 0915051 )

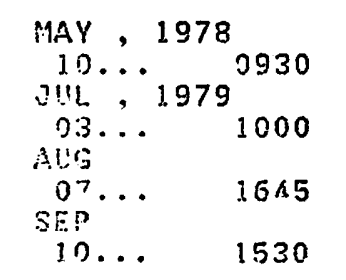

$\begin{array}{rr}38 & 350 \\ .01 & 320 \\ .20 & 550 \\ .30 & 495\end{array}$

$\begin{array}{ll}7.6 & 14.0 \\ 7.6 & 25.0 \\ 8.2 & 31.0 \\ 7.6 & 22.0\end{array}$

$\begin{array}{rr}25 & 39 \\ 160 & 250 \\ 40 & 3.5 \\ 10 & 6.1\end{array}$

9.8
5.5
5.8
8.2

97
67
79
95

$\begin{array}{rrr}250 & 140 & 170 \\ 3100 & 2300 & 110 \\ <20 & 4700 & 230 \\ 230 & 200 & 240\end{array}$


Table 2

\begin{tabular}{|c|c|c|c|c|c|c|c|c|c|c|c|c|}
\hline & $\begin{array}{l}\text { CALCIUM } \\
\text { DIS- } \\
\text { SOLVED } \\
\text { (MG/L } \\
\text { AS CA) }\end{array}$ & $\begin{array}{c}\text { MAGNE - } \\
\text { SIUM, } \\
\text { DIS- } \\
\text { SOLVED } \\
\text { (MG/L } \\
\text { AS MG) } \\
(00925)\end{array}$ & $\begin{array}{l}\text { SODIUM, } \\
\text { DIS- } \\
\text { SOLVED } \\
\text { (MG/L } \\
\text { AS NA) } \\
(00930)\end{array}$ & $\begin{array}{l}\text { POTAS- } \\
\text { SIUM, } \\
\text { DIS- } \\
\text { SOLVED } \\
\text { (MG/L } \\
\text { AS K ) } \\
\text { (00935) }\end{array}$ & $\begin{array}{c}\text { BICAR- } \\
\text { BONATE } \\
\text { (MG /L } \\
\text { AS } \\
\text { HCO3) }\end{array}$ & $\begin{array}{c}\text { SULFATE } \\
\text { DIS- } \\
\text { SOLVED } \\
\text { (MG/L } \\
\text { AS SO4) } \\
(00945)\end{array}$ & $\begin{array}{l}\text { CHLO- } \\
\text { RIDE, } \\
\text { DIS- } \\
\text { SOLVED } \\
\text { (MG/L } \\
\text { AS CL ) } \\
\text { (00940) }\end{array}$ & $\begin{array}{l}\text { FLUO- } \\
\text { RIDE, } \\
\text { DIS- } \\
\text { SOLVED } \\
\text { (MG/L } \\
\text { AS F) } \\
\text { (00950) }\end{array}$ & $\begin{array}{l}\text { RESIDUE } \\
\text { AT } 180 \\
\text { DEG.C } \\
\text { DIS- } \\
\text { SOLVED } \\
\text { (MG/L) } \\
(70300)\end{array}$ & $\begin{array}{l}\text { SOL IDS, } \\
\text { RESIDUE } \\
\text { AT } 105 \\
\text { DEG. C, } \\
\text { SUS- } \\
\text { PENDED } \\
\text { \{MG/L) } \\
\{00530\}\end{array}$ & $\begin{array}{l}\text { SOLIDS, } \\
\text { RESIDUE } \\
\text { AT } 105 \\
\text { DEG C } \\
\text { TOTAL, } \\
(M G / L) \\
(00500)\end{array}$ & $\begin{array}{c}\text { NITRO- } \\
\text { GEN, } \\
\text { NO2+NO3 } \\
\text { TOTAL } \\
\text { (MG/L } \\
\text { AS N) } \\
(00630)\end{array}$ \\
\hline
\end{tabular}

05490536 - BIG INDIAN C NO. I NR LEBANON, IA (LAT 404204 LONG 0920239 )

:

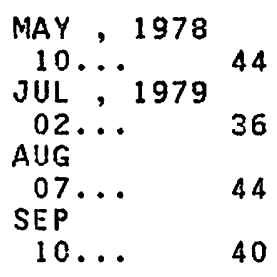

$\begin{array}{lll}12 & - & - \\ 11 & -- & - \\ 12 & - & - \\ 11 & 7.7 & 9.0\end{array}$

$--$

$-$

$-$

$$
-
$$$$
--\quad 203
$$

33

238

$\begin{array}{lll}-- & -- & 206\end{array}$

55

250

.84

$$
-
$$$$
--
$$$$
--
$$

$$
432
$$

3.4 .03

05490540 - BIG INDIAN C NO. 2 NR KEOSAUQUA, IA (LAT 404114 LONG 0915946 )

$\begin{array}{ccccccccccc}12 & -- & -- & -- & -- & -- & -- & 198 & 82 & 319 & .80 \\ 9.8 & -- & -- & -- & -- & -- & -- & 246 & 258 & 488 & 5.5 \\ 35 & -- & -- & -- & -- & -- & -- & 214 & 12 & 228 & .05 \\ 9.7 & 9.6 & 7.8 & 160 & 13 & 6.7 & .3 & 188 & 27 & 208 & .05\end{array}$

05490550 - BIG INDIAN C NO. 3 NR MT. STERLING, IA (LAT 403741 LONG 0915051 )

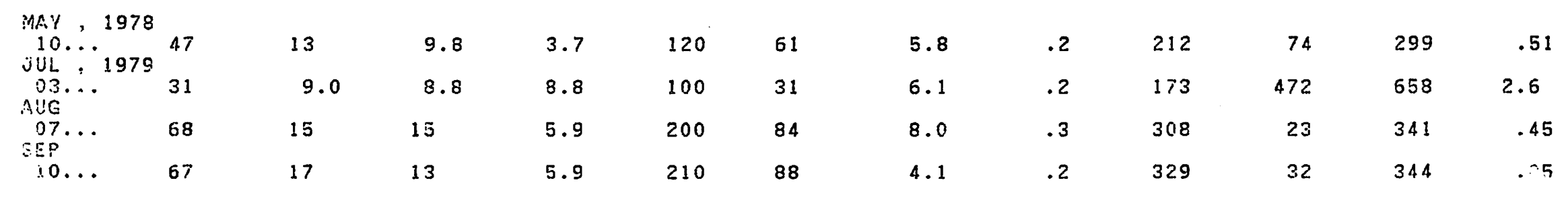


Table 2

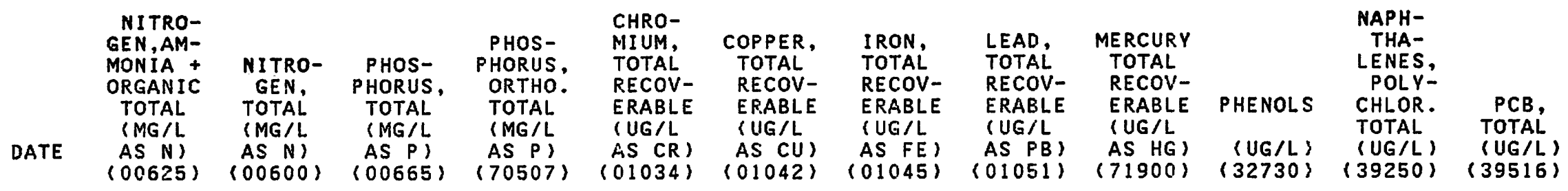

05490536 - BIG INDIAN C NO. 1 NR. LEBANON, IA (LAT 404204 LONG 0920239 )

\begin{tabular}{|c|c|c|c|c|c|c|c|c|c|c|c|c|}
\hline $\begin{array}{l}\text { MAY , } 1978 \\
10 . .\end{array}$ & 1.2 & 2.0 & .13 & .04 & 0 & 8 & 1400 & 14 & .0 & 8 & .00 & .0 \\
\hline $02 . .$. & 1.6 & 5.0 & .14 & .07 & 10 & 40 & 2200 & 19 & .3 & 1 & -- & .0 \\
\hline & 5.6 & 5.6 & .51 & .10 & 20 & 10 & 18000 & 19 & .0 & 11 & -- & .0 \\
\hline $10 \ldots$ & 2.9 & 3.0 & .29 & .08 & 20 & 9 & 6400 & 9 & 0 & 3 & 00 & .0 \\
\hline
\end{tabular}

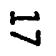

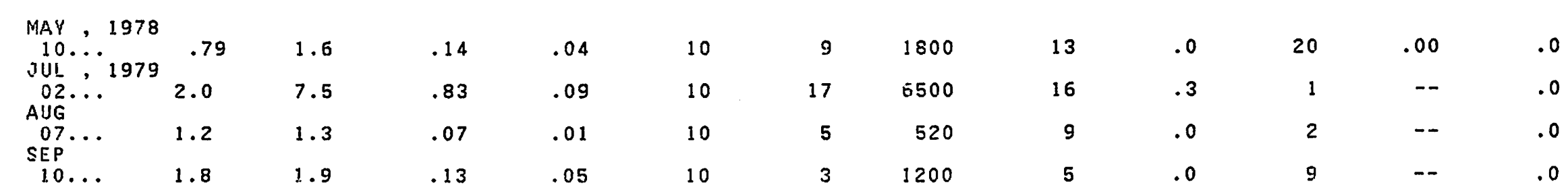

05490550 - BIG INDIAN C NO. 3 NR MT. STERLING, IA (LAT 403741 LONG 0915051 )

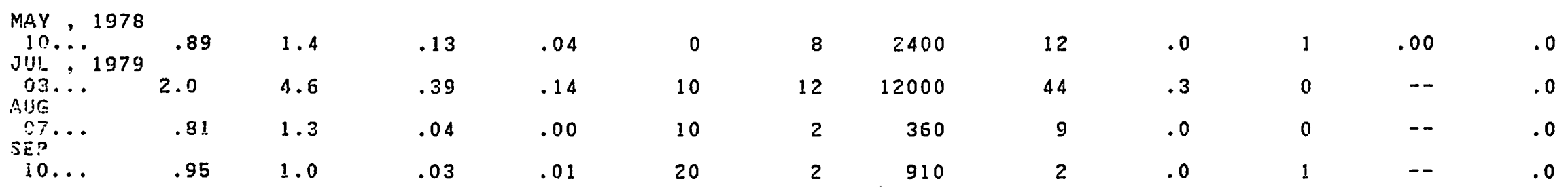




\section{Table 2}

\begin{tabular}{|c|c|c|c|c|c|c|c|c|c|c|c|}
\hline DATE & $\begin{array}{c}\text { ALDRIN, } \\
\text { TOTAL } \\
(U G / L) \\
(39330)\end{array}$ & $\begin{array}{l}\text { CHLOR- } \\
\text { DANE, } \\
\text { TOTAL } \\
\text { (UG/L) } \\
(39350)\end{array}$ & $\begin{array}{c}\text { DDD, } \\
\text { TOTAL } \\
\text { (UG/L) } \\
(39360)\end{array}$ & $\begin{array}{c}\text { DDE, } \\
\text { TOTAL } \\
\text { \{UG/L\} } \\
\{39365\}\end{array}$ & $\begin{array}{c}\text { DDT, } \\
\text { TOTAL } \\
(\text { UG/L) } \\
(39370\}\end{array}$ & $\begin{array}{c}\text { DI- } \\
\text { AZINON, } \\
\text { TOTAL } \\
\text { (UG/L) } \\
(39570)\end{array}$ & $\begin{array}{l}\text { DI- } \\
\text { ELDRIN } \\
\text { TOTAL } \\
\text { (UG/L) } \\
(39380)\end{array}$ & $\begin{array}{l}\text { ENDO- } \\
\text { SULFAN, } \\
\text { TOTAL } \\
\text { (UG/L) } \\
(39388)\end{array}$ & $\begin{array}{c}\text { ENDRIN, } \\
\text { TOTAL } \\
\text { (UG/L) } \\
(39390)\end{array}$ & $\begin{array}{c}\text { ETHION, } \\
\text { TOTAL } \\
\text { (UG/L) } \\
(39398)\end{array}$ & $\begin{array}{l}\text { HEPTA- } \\
\text { CHLOR, } \\
\text { TOTAL } \\
\text { (UG/L) } \\
(39410)\end{array}$ \\
\hline
\end{tabular}

05490536 - EIG INDIAN C NO. 1 NR LEBANON, IA \{LAT 404204 LONG 0920239 )

\begin{tabular}{|c|c|c|c|c|c|c|c|c|c|c|c|}
\hline $\begin{array}{l}\text { MAY }, 1978 \\
10 \ldots \cdots 1979\end{array}$ & .00 & .0 & .00 & .00 & .00 & .01 & .01 & .00 & .00 & .00 & .00 \\
\hline AUG & .00 & .0 & .00 & .00 & .00 & .02 & .01 & .00 & .00 & .00 & .00 \\
\hline SEP & .00 & .0 & .00 & .00 & .00 & .00 & .01 & .60 & .00 & .00 & .00 \\
\hline $10 \ldots$ & .00 & .0 & .00 & .00 & .00 & .00 & .00 & .00 & .00 & .00 & .00 \\
\hline
\end{tabular}

05490540 - BIG INDIAN C NO. 2 NR KEOSAUQUA, IA (LAT 404114 LONG 091 5946)

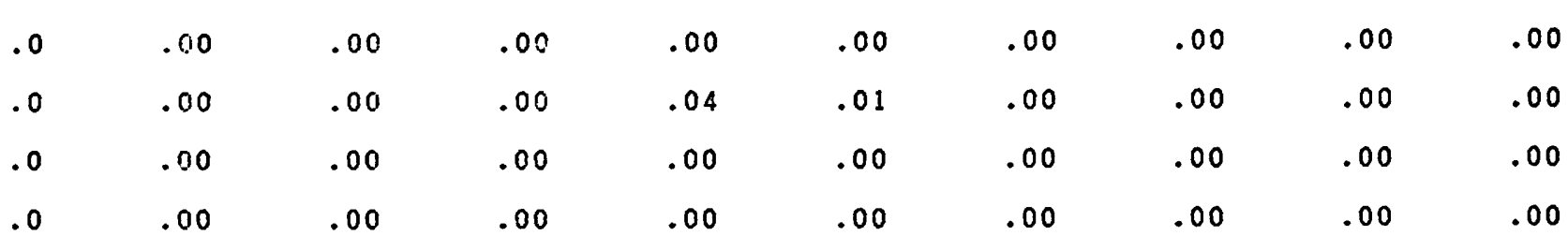

05490550 - BIG INDIAN C NO. 3 NR MT. STERLING, IA (LAT 403741 LONG 0915051 )

$$
\begin{aligned}
& \text { MAY , } 1978 \\
& \text { JUL, } 1979.00 \\
& 03 . . \\
& .00 \\
& 07 \ldots .00 \\
& \text { OF... } \\
& 10 \ldots \\
& .00
\end{aligned}
$$

$\begin{array}{lllll}.0 & .00 & .00 & .00 & .00 \\ .0 & .00 & .00 & .00 & .02 \\ .0 & .00 & .00 & .00 & .00 \\ .0 & .00 & .00 & .00 & .00\end{array}$

$\begin{array}{ll}.00 & .00 \\ .00 & .00 \\ .00 & .00 \\ .00 & .00\end{array}$

$\begin{array}{lll}.00 & .00 & .00 \\ .00 & .00 & .00 \\ .00 & .00 & .00 \\ .00 & .00 & .00\end{array}$


Table 2

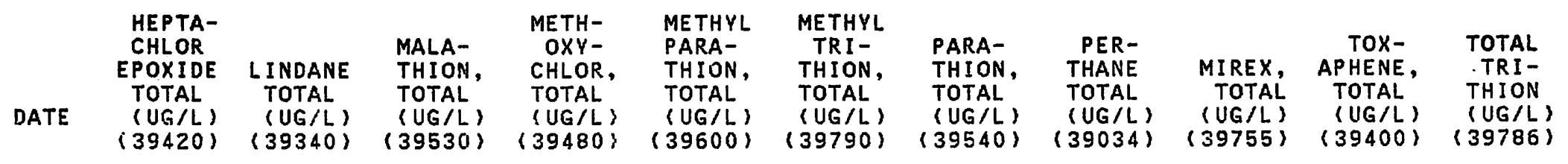

05490536 - EIG INDIAN C NO. 1 NR LEBANON, IA (LAT 404204 LONG 09202 39)

\begin{tabular}{|c|c|c|c|c|c|c|c|c|c|c|c|}
\hline $\begin{array}{l}\text { MAY }, 1978 \\
10 . . .\end{array}$ & .00 & .00 & .00 & -- & .00 & .00 & .00 & .00 & -- & 0 & .00 \\
\hline $02 \ldots$ & .00 & .00 & .00 & .00 & .00 & .00 & .00 & .00 & .00 & 0 & .00 \\
\hline $\begin{array}{l}\text { AUG } \\
\text { OA. . . }\end{array}$ & .00 & .00 & .00 & .00 & .00 & .00 & .00 & .00 & .00 & 0 & .00 \\
\hline $10 \ldots$ & .00 & .00 & .00 & .00 & .00 & .00 & .00 & .00 & .00 & 0 & .00 \\
\hline
\end{tabular}

05490540 - BIG INDIAN C NO. 2 NR KEOSAUQUA, IA (LAT 404114 LONG 0915946 )

MAY, 1978

J10.? 1979

02 .

.00

.00

.00

$-.00$

$.00 \quad .00$

.00

$-$

$0 \quad .00$
0

AUG

.00

$.00 \quad .00$

.00

$.00 \quad .00$

.00

0

.00

SEP $\cdots$

.00

$.00 \quad .00$

$.00 \quad .00$

$.00 \quad .00$

.00

.00

$0 \quad .00$

$10 \ldots .00$

.00

$.00 \quad .00$

$.00 \quad .00$

.00

.00

0

.00

05490550 - BIG INDIAN C NO. 3 NR MT. STERLING, IA (LAT 403741 LONG 0915051 )

\begin{tabular}{|c|c|c|c|c|c|c|c|c|c|c|c|}
\hline $\begin{array}{l}\text { MAY , } 1978 \\
10 . . .\end{array}$ & .00 & .00 & .00 & -- & .00 & .00 & .00 & .00 & -- & 0 & .00 \\
\hline 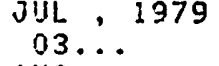 & .01 & .00 & .00 & .00 & .00 & .00 & .00 & .00 & .00 & 0 & .00 \\
\hline $\begin{array}{l}\text { AüG } \\
\text { o7... }\end{array}$ & & & & & & & & & & & \\
\hline SEP $\cdots$ & .01 & .00 & .00 & .00 & .00 & -- & .00 & .00 & .00 & 0 & .00 \\
\hline 1 & .00 & .00 & . 110 & 00 & 00 & 00 & 0 & 00 & & & .00 \\
\hline
\end{tabular}

